\title{
ANALISIS PENERAPAN PMK NO.136/PMK.03/2012 TENTANG PENUNJUKAN BUMN SEBAGAI WAPU PPN (Studi Pada PT. Pertamina Geothermal Energi Area Kamojang)
}

\author{
Norma Etika Wati ${ }^{1}$, Kamalah Saadah ${ }^{2)}$ \\ ${ }^{1)}$ Jurusan Akuntansi, Politeknik Negeri Bandung, \\ Jl. Geger Kalong Hilir, Bandung \\ ${ }^{1)}$ Email: Norma.etika.akun415@polban.ac.id \\ ${ }^{2)}$ Jurusan Akuntansi, Fakultas Ekonomi, Universitas Swadaya Gunung Jati \\ Jl. Pemuda No 32, Cirebon \\ ${ }^{2)}$ Email: kamalah.mala@gmail.com
}

Diterima: 10 Maret 2020. Disetujui: 06 Mei 2020. Dipublikasikan: Juni 2020

\begin{abstract}
ABSTRAK
Penelitian ini bertujuan untuk mengetahui gambaran dan analisis mengenai penerapan PMK No.136/PMK.03/2012 yang mencakup prosedur pembayaran, penyetoran dan pelaporan Pajak Pertambahan Nilai pada PT Pertamina Geothermal Energy (PGE) Area Kamojang. Metode yang digunakan dalam penelitian ini adalah metode kualitatif deskriptif dan teknik pengumpulan data dengan cara observasi,wawancara dan dokumentasi. Sumber data yang digunakan dalam penelitian ini adalah data primer dan sekunder. Penelitian ini menghasilkan gambaran bahwa kewajiban PT PGE Area Kamojang sebagai Wajib Pungut Pajak Pertambahan Nilai (Wapu PPN) telah dilaksanakan dengan baiksesuai dengan PMK No.136/PMK.03/2012, namun pada saat pelaksaannya ditemukan kesalahan dari perusahaan rekanan yang mengakibatkan keterlambatan. Dampak lebih lanjut akan menimbulkan pengenaan denda adminitrasi bagi kedua belah pihak. Penelitian ini diharapkan memberikan kontribusi masukan mengenai Pajak Pertambahan Nilai bagi PT PGE Area Kamojang sehingga menjadi perusahaan yang lebih tertib dalam administrasi perpajakan. Hasil observasi yang telah dilakukan menunjukan bahwa terdapat beberapa ketidaksesuaian dalam hal pelaksanaan prosedur pembayaran Pajak Pertambahan Nilai. Akibatnya, apabila tidak terpenuhi maka terdapat sanksi atas keterlambatan penyetoran dan pelaporan pajak tersebut.
\end{abstract}

Kata Kunci : Wapu PPN,PMK No.136/PMK.03/2012,Keterlambatan Pajak

\section{ABSTRACT}

This study aims to determine the description and analysis of the application of PMK No.136 / PMK.03 / 2012 which includes payment, deposit and reporting procedures for Value Added Tax at PT Pertamina Geothermal Energy (PGE) Kamojang Area. The method used in this research is descriptive qualitative method with data collection techniques by observation, interview and documentation. Data sources used in this study are primary and secondary data. This study produces a description that the obligations of PT PGE Kamojang Area as a Value Added Tax Taxpayer have been carried out properly in accordance with PMK No.136 / PMK.03 / 2012, but at the time of its implementation found errors from partner companies which resulted in delays. Further impacts will lead to the imposition of administrative fines for both parties. This research is expected to contribute input regarding Value Added Tax for PT PGE Kamojang Area to become a more orderly company in tax administration. The observations that have been made show that there are some discrepancies in the implementation of the Value Added Tax payment procedure. As a result, if it is not met, there will be sanctions for the delay in depositing and reporting the tax.

Keywords: VAT mandatory collection, PMK No.136 / PMK.03 / 2012, Tax Delay 


\section{PENDAHULUAN}

Pajak merupakan sektor yang paling diandalkan bagi pemasukan negara. Sebagai bukti, realisasi penerimaan pajak pada 31 Agustus 2018 mencapai $60,84 \%$ dari total pendapatan negara dan pada 31 Desember 2018 realisasi penerimaan pajak mencapai 71,39\% dari targetnya. Berdasarkan prosentase capaian penerimaan pajak terhadap total pendapatan negara yakni 60,84\% tersebut, penerimaan Pajak Pertambahan Nilai (PPN) mengambil peran sebesar 56,77\%. Kontribusi BUMN dalam memungut PPN terhadap kas negara adalah 28\%. Pada pelaksanaannya, Menteri Keuangan menunjuk BUMN sebagai Wajib Pungut (Wapu) PPN sesuai dengan PMK No.136/PMK.03/2012.

Wajib pungut PPN menggunakan suatu mekanisme pemungutan pajak yakni withholding tax system sehingga berkewajiban untuk memotong PPN kepada perusahaan rekanan. Adapun konsekuensi yang harus ditanggung apabila terbukti dari pemeriksaan fiskus bahwa wapu PPN tidak memenuhi kewajiban tersebut, maka perusahaan berkewajiban untuk membayar withholding tax tersebut ditambah denda keterlambatan penyetoran. (Suandy, 2011)

PT Pertamina Geothermal Energy (PT. PGE) Area Kamojang merupakan salah satu perusahaan BUMN yang ditunjuk sebagai wajib pungut PPN. Kontribusinya dalam memungut PPN terhadap perusahaan rekanan pun cukup besar, yakni Rp. 6,250 M atau 2,26\% dari total penerimaan pajak BUMN di semua sektor.

Realisasi dari pelaksanaan mekanisme withholding tax yang dilaksanakan PT. PGE Area Kamojang tersebut tentunya tidak sepenuhnya dapat dijalankan dengan baik. Hal ini disebabkan perusahaan BUMN harus berhubungan dengan perusahaan rekanan yang mana tidak semua perusahaan rekanan mampu menjalankan administrasi perpajakan sesuai dengan peraturan yang berlaku. Sebagai gambaran, selama tahun 2012 hingga tahun 2018 perusahaan rekanan membuat faktur pajak yang tidak sama dengan periode penyerahan barang dan jasa kena pajak sehingga menyebabkan PT. PGE tidak dapat melaksanakan pelaporan tepat waktu. Dampaknya, denda administrasi akan dikenakan. Perusahaan rekanan harus melakukan pembetulan disesuaikan dengan masa pajaknya.

Gambaran permasalahan lain yakni pada tahun 2013 terdapat vendor yang tidak dapat melakukan pembayaran pada tanggal 25 di bulan yang bersangkutan namun tidak merubah faktur pajaknya dengan alasan waktu tersebut terhambat oleh closing keuangan PT.PGE. Hal ini dapat menyebabkan pengenaan denda dari pihak perpajakan, namun hingga saat ini belum terdapat temuan akan hal tersebut.

Pada tahun 2014 pun terjadi permasalahan yaitu banyak vendor melakukan penyetoran dan pelaporan PPN dengan cara disetahunkan. Akibatnya pada bulan-bulan terkait tidak terdapat transaksi. Transaksi-transaksi tersebut akan muncul sekaligus pada akhir tahun. Pada akhirnya vendor pun akan meminta bukti potong untuk masa satu tahun. Hal ini mengakibatkan perlunya penanganan yang lebih intensif bagi departemen Administrasi Perpajakan di PT PGE Area Kamojang.

Permasalahan di tahun 2016, dapat dilihat dari penyerahan faktur pajak vendor yang tidak valid. Akibatnya vendor harus melakukan pembetulan faktur pajak dengan monitoring langsung agar faktur pajak yang dihasilkan dapat dijamin validitasnya sehingga faktur pajak tersebut dapat diproses lebih lanjut dan dilakukan penginputan.

Permasalahan Nomor Pokok Wajib Pajak (NPWP) terjadi di tahun 2017. Hal ini dikarenakan PT. PGE memiliki lebih dari satu NPWP sehinga akan menimbulkan kebingungan bagi vendor yang seharusnya mencantumkan NPWP.PGE Pusat (Jakarta). Dalam hal ini, vendor harus melakukan pembetulan faktur dengan kode 031.

Permasalahan prosedur pelaksanaan pembayaran PPN terdapat di tahun 2018. Kadang kala vendor tidak menyerahkan bukti pembayaran pajak atau Surat Setoran Pajak (SSP) dan dalam transaksinya pun tidak terdapat pajak keluaran. Selain itu, terdapat kesalahan vendor dalam input nomor seri faktur pajak, tanggal, dan ketidaksesuaian alamat.

Penelitian sebelumnya dilakukan oleh Supriano Eko (2015) yang menyatakan bahwa PT. Semen Indonesia (Persero) Tbk sudah menerapkan PMK No.136/PMK.03/2012, namun 
ditemukan kesalahan perhitungan PPN yang dilakukan oleh karyawannya di tahun 2013. Penelitian lainnya dilakukan oleh Hafidhotul Ilmi (2016) yang menghasilkan kesimpulan bahwa PT. Jen Tsong Indonesia telah melakukan perhitungan dan penyetoran PPN sesuai denganUU No, 42 tahun 2009 namun terdapat kesalahan dalam pencatatan tanggal pelaporan. Selain itu terdapat permasalahan atas faktur pajak yang kurang lengkap.

PT. PGE Area Kamojang sebagai Wapu PPN harus memahami serta mematuhi Peraturan Menteri Keuangan No. 136/PMK.03/2012. Ruang lingkup PMK ini meliputi kriteria BUMN yang ditunjuk sebagai Pemungut PPN, administrasi penerbitan Faktur Pajak oleh PKP Rekanan, serta administrasi pemungutan, penyetoran dan pelaporan PPN dan PPnBM oleh BUMN sebagai Pemungut PPN.

Permasalahan-permasalahan yang telah diungkapkan sebelumnya akan menimbulkan keterlambatan dalam penyetoran PPN. Atas dasar hal tersebut, akan diterima konsekuensi pengenaan denda atas keterlambatan yakni $2 \%$ per bulan paling lama 24 bulan dari besarnya pajak piutang kepada negara (pasal 14 ayat 4), denda 200\% dengan kurungan maksimal satu tahun (pasal 38) dan denda 400\% dengan kurungan paling lama 6 tahun (pasal 39). Dengan dipahaminya PMK tersebut diharapkan PT. PGE Area Kamojang dapat meminimalisir konsekuensi keterlambaran penyetoran PPN serta dapat lebih meningkatkan ketertiban administrasi perpajakan PT. PGE itu sendiri.

Berdasarkan fenomena di atas, maka penulis tertarik untuk melakukan analisis dan evaluasi mengenai Pelaksanaan Penyetoran PPN yang telah dilakukan PT PGE Area Kamojang berdasarkan Peraturan Menteri Keuangan No.136/PMK.03/2012 mengenai Tata Cara Pelaksanaan Pembayaran PPN sebagai Wajib Pungut untuk Perusahaan BUMN. Penelitian ini menggunakan metode kualitatif deskriptif sehingga diharapkan informasi yang dibutuhkan dapat tergali secara efektif. Mengacu pada pemaparan sebelumnya, penulis akan mengangkat judul tentang "Analisis Penerapan Peraturan Menteri Keuangan No.136/PMK.03/2012 tentang penunjukan BUMN sebagai Wajib Pungut Pajak Pertambahan Nilai pada PT Geothermal Energy Area Kamojang”.

\section{TINJAUAN PUSTAKA \\ 2.1 Pajak}

Menurut pasal 1 ayat 1 UU No.16 Tahun 2009 pengertian pajak adalah:

"Pajak adalah kontribusi wajib kepada Negara yang terutang oleh orang pribadi atau badan yang bersifat memaksa berdasarkan Undang-Undang, dengan tidak mendapatkan imbalan secara langsung dan digunakan untuk keperluan negara bagi sebesar-besarnya kemakmuran rakyat."

Pengertian pajak menurut mardiasmo (2011) "pajak adalah iuran rakyat kepada kas negara berdasarkan undang-undang atau yang dapat dipaksakan dengan tiada mendapat jasa timbal (kontrasepsi) yang langsung dapat ditunjukkan dan yang digunakan untuk membayar pengeluaran umum". Berdasarkan pengertian tersebut peneliti sampai pada pemahaman bahwa pajak merupakan pembayaran wajib kepada kas negara yang bersifat memaksa untuk pendapatan ekonomi sebuah negara yang mengacu pada undang-undang serta aturan mengenai perpajakan.

\subsection{Pajak Pertambahan Nilai}

Pajak Pertambahan Nilai (PPN) didefinisikan sebagai "pajak atas konsumsi di wilayah Pabean, konsumsi tersebut meliputi barang maupun jasa" (Waluyo : 2009). Selain itu Mardiasmo (2011) melihat PPN dari sudut pandang sejarah, PPN merupakan pajak pengganti dari pajak penjualan. Sedangkan perbedaan pandangan yang dijelaskan oleh Undang-Undang No.42 Tahun 2009 mengenai definisi PPN terletak pada sudut pandang bahwa PPN merupakan pajak yang dikenakan pada setiap jalur distribusi dan produksi. Berdasarkan penjelasanpenjelasan tersebut, dapat diketahui bahwa PPN merupakan pajak yang dikenakan atas konsumsi barang dan jasa pada setiap jalur produksi dan distribusi di wilayah pabean. 


\subsubsection{Dasar Hukum Pajak Pertambahan Nilai (PPN)}

Peraturan Perundang-undangan mengenai PPN yaitu Undang-Undang Nomor 8 Tahun 1983 tentang PPN dan PPnBM. Peraturan tersebut telah diubah dengan UU No.18 Tahun 2000 tentang Pajak Pertambahan Nilai (PPN) atas Barang dan Jasa terkait pajak penjualan. Selanjutnya undang undang terbaru mengenai pajak tersebut adalah UU No.42 Tahun 2009.

\subsection{Barang Kena Pajak (BKP) dan Jasa Kena Pajak (JKP)}

Pengertian Barang Kena Pajak (BKP) menurut Waluyo (2011) adalah "barang berwujud yang menurut sifat atau hukumnya dapat berupa barang bergerak atau barang tidak bergerak dan barang tidak berwujud yang dikenai pajak berdasarkan UU PPN dan PPnBM)" Menurut UU No. 18 Tahun 2000 dan No. 42 Tahun 2009 pasal 1 angka (6) PKP adalah setiap kegiatan pelayanan berdasarkan suatu perikatan atau perbuatan hukum yang menyebabkan suatu barang atau fasilitas atau memberi kemudahan atau hak tersedia untuk dipakai, termasuk jasa yang dilakukan untuk menghasilkan barang karena pesanan dan bahan dan petunjuk pemesan.

Berdasarkan pengertian di atas dapat diketahui bahwa barang dan jasa kena pajak adalah setiap barang berwujud yang bergerak ataupun tidak bergerak jika ditinjau dari segi hukum, yang dikenai pajak.

\subsection{Tarif Pajak Pertambahan Nilai}

Menurut Undang-Undang Nomor 42 Tahun 2009 pada pasal 7 ayat 2, tarif PPN dan PPnBM adalah sebagai berikut:

1. Tarif PPN adalah $10 \%$ (sepuluh persen).

2. Tarif PPN sebesar 0\% (sepuluh persen) diterapkan atas ekspor Barang Kena Pajak (BKP) Berwujud, ekspor BKP Tidak Berwujud; dan ekspor Jasa Kena Pajak.

3. Tarif PPnBM adalah paling rendah $10 \%$ (sepuluh persen) dan paling tinggi $200 \%$ (dua ratus persen).

4. Sedangkan tarif PPnBM atas ekspor BKP yang tergolong mewah adalah 0\% (nol persen)

\subsection{Denda Administrasi}

Menurut UU KUP Nomor 16 Tahun 2009, konsekuensi yang harus ditanggung oleh

BUMN apabila tejadi kegagalan dalam pelaksanaan kewajiban sebagai wajib pungut yaitu:

- Sanksi administrasi sebesar Rp. 500.000,00 (pasal 7), jika Surat Pemberitahuan Masa tidak disampaikan tepat waktu.

- Sanksi 2\% perbulan (pasal 8 ayat 2a), jika membetulkan sendiri Surat Pemberitahuan Masa yang mengakibatkan utang pajak menjadi lebih besar.

- Sanksi $2 \%$ perbulan paling lama 24 bulan (pasal 14 ayat 3), jika dari hasil penelitian terdapat kekuranagn pembaaran pajak akibat salah tulis dan/atau salah hitung.

- Denda maksimal 200\% atau pidana kurungan maksimal 1 tahun (pasal 38), jika tidak menyampaikan Surat Pemberitahuan atau menyampaikan tetapi isinya tidak benar atau tidak lengkap, atau melampirkan keterangan yang isinya tidak benar sehingga dapat menimbulkan kerugian pada pendapatan negara dan perbuatan tersebut bukan merupakan pertama kali.

\section{METODOLOGI PENELITIAN}

\subsection{Objek dan Metode Penelitian}

Objek dari penelitian ini yaitu Pajak Pertambahan Nilai, dan metode yang digunakan oleh penulis adalah metode kualitatif deskriptif. Pengumpulan, penyajian dan penggambaran mengenai perhitungan, pemungutan pelaporan dan penyetoran PPN di perusahaan yang menjadi objek penelitian menupakan cara peneliti dalam mendapatkan data penelitian. Upaya ini dilakukan dengan tujuan agar dapat dilakukan analisis yang komprehensif. 


\subsection{Sumber Data}

Data yang digunakan dalam penelitian ini bersumber dari hasil wawancara terhadap narasumber (data primer) dan data terkait jumlah PPN serta dokumen lain mengenai PT. PGE Area Kamojang (data sekunder). Kedua sumber data tersebut saling menunjang dalam membangun hasil penelitian.

\subsection{Analisis Data dan Pengolahan Data}

Data yang akan dikumpulkan untuk diolah dan dianalisis dalam penelitian ini mencakup data jumlah PPN yang dibatasi dari Tahun 2015-2017 dan tahun 2018 Triwulan I (bulan Januari sampai dengan Maret). Setelah data tersebut dikumpulkan, kemudian dilakukan analisis kesesuaian realisasi pelaksanaan mekanisme perhitungan, pemungutan penyetoran dan pelaporannya.

\section{HASIL PENELITIAN DAN PEMBAHASAN}

\subsection{Analisis Perolehan Barang Kena Pajak (BKP)}

PPN masukan timbul karena entitas membeli barang dari pihak lain dan dikenakan Pajak Pertambahan Nilai. Berikut disajikan grafik jumlah PPN masukan yang dibayar oleh PT. PGE dari tahun 2015 hingga tahun 2018 Triwulan 1:

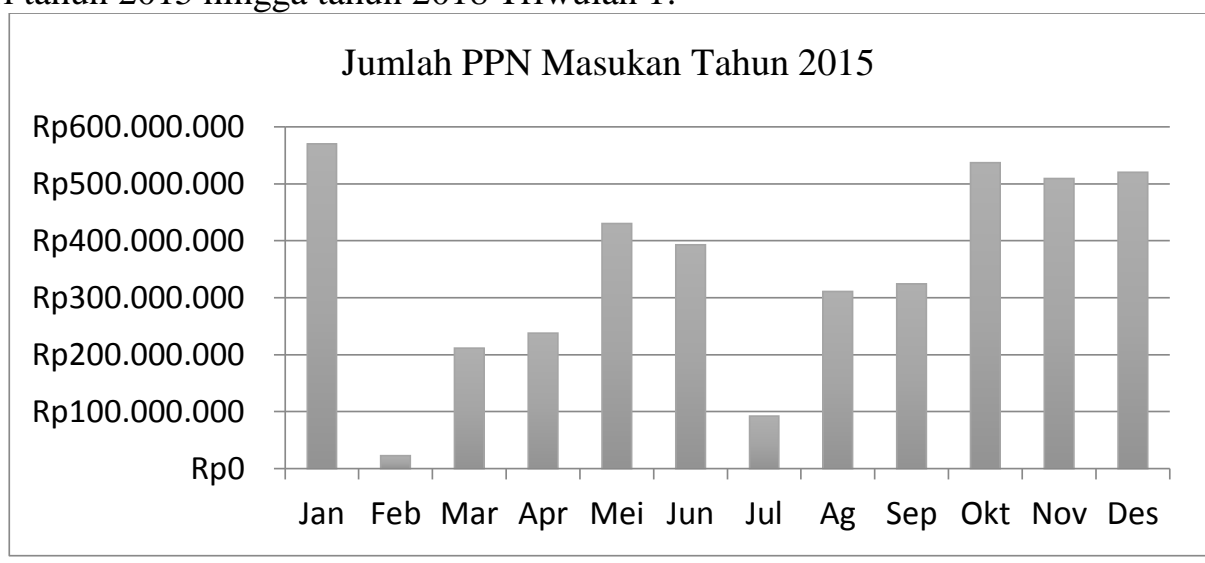

Gambar 1. Grafik Jumlah PPN Masukan Tahun 2015

Berdasarkan Gambar 1, dapat diketahui bahwa pajak masukan tertinggi terdapat di bulan Januari yakni sebesar Rp. 570.103.485,- dan pajak masukan terendah berada di bulan Februari (Rp. 22.399.707,-). Selanjutnya akan digambarkan data jumlah PPN masukan untuk tahun 2016 sebagai berikut:

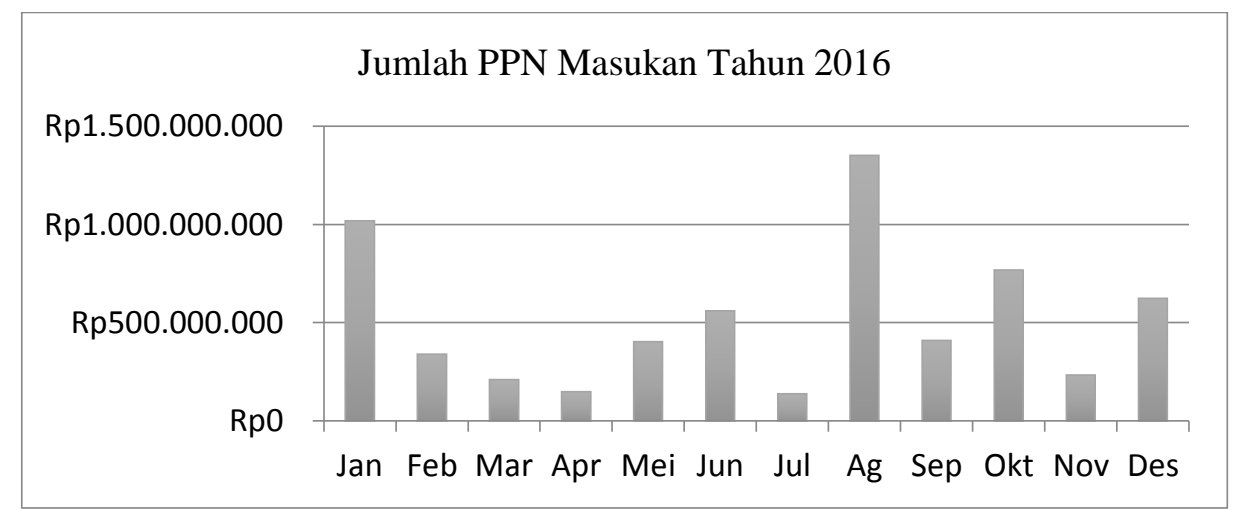

Gambar 2. Grafik Jumlah PPN Masukan Tahun 2016

Berdasarkan Gambar 2, dapat diketahui bahwa jumlah pajak masukan terbanyak yang dilakukan oleh PT. PGE Area Kamojang berada di bulan Agustus yaitu sebesar Rp. 1.353.150.549,- dan pajak masukan terendah berada di bulan Juli yakni Rp. 137.315.948,-. 
Berikutnya akan gambarkan grafik jumlah PPN masukan untuk tahun 2017:

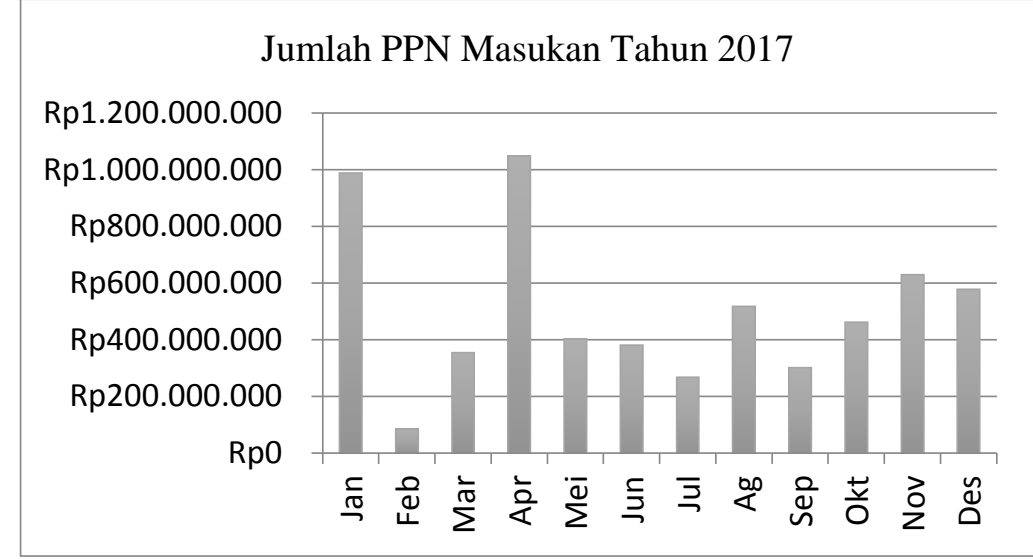

Gambar 3. Grafik Jumlah PPN Masukan Tahun 2017

Berdasarkan ggrafik jumlah PPN masukan tahun 2017 pada gambar 3 dapat diketahui bahwa jumlah PPN masukan tertinggi berada di bulan April yaitu sebesar Rp 1,048,115,642,- dan PPN masukan terendah berada di bulan Februari yakni sebesar Rp. 84,671,469,-. Selanjutnya akan digambarkan grafik mengenai PPN masukan untuk tahun 2018 Triwulan I:

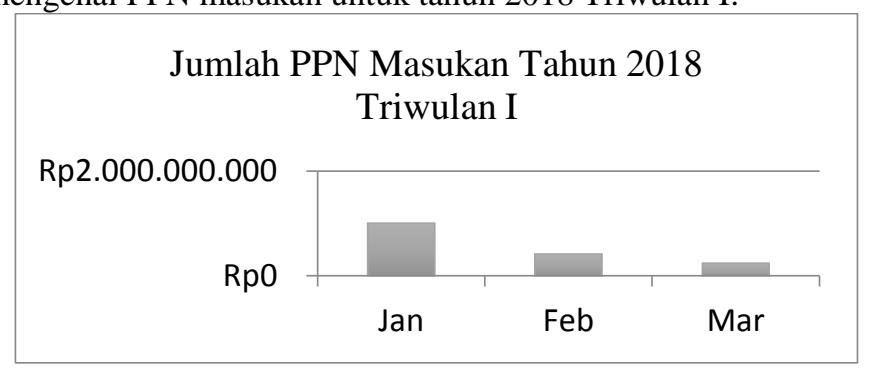

Gambar 4. Grafik Jumlah PPN Masukan Tahun 2018 Triwulan I

Berdasarkan Gambar 4 mengenai jumlah PPN masukan tahun 2018 triwulan 1, dapat dilihat bahwa jumlah PPN masukan tertinggi berada di bulan Januari, yakni sebesar Rp. 1,007,085,114,- sedangkan jumlah PPN masukan terendah berada di bulan Maret yakni sebesar Rp. $240,669,842,-$.

\subsection{Analisis Perhitungan Pajak Pertambahan Nilai}

Perhitungan tarif PPN Nilai yang telah dilakukan oleh PT PGE Area Kamojang sudah sesuai dengan aturan perpajakan, yaitu sepuluh persen dari dasar pengenaan pajak sehingga dapat dikatakan bahwa PMK No.136/PMK.03/2012 telah dilaksanakan oleh PT. PGE Area Kamojang. Penelitian ini selaras dengan penelitian Supriano (2015) yang menyatakan bahwa PT. Semen Indonesia (Persero) Tbk telah menerapkan PMK No.136/PMK.03/2012 dalam hal perhitungan PPN. Selain itu, penelitian ini juga berkaitan dengan Undang-Undang 42 tahun 2009 pada pasal 7 ayat 2 mengenai tarif PPN sebesar 10\% dan tarif PPN 0\% atas Ekspor Barang Kena Pajak Berwujud dan tidak berwujud serta Ekspor Jasa Kena Pajak.

\subsection{Analisis Pemungutan Pajak Pertambahan Nilai}

Sebagai wajib pungut PPN, PT. PGE Area Kamojang telah melaksakan tugas pemungutan PPN dengan baik sesuai dengan PMK No.136/PMK.03/2012. Faktur pajak pun dibuat tiga rangkap sesuai ketentuan. Namun pada tahun 2018 ditemukan permasalahan terhadap faktur pajak yang diberikan oleh vendor. Kesalahan tersebut diantaranya adalah kesalahan dalam pemberian nomor seri faktur pajak, penulisan tanggal dan alamar yang tidak sesuai dan kecacatan faktur pajak. Hal ini memungkinkan untuk mencantumkan kode 031 atas pembetulan kembali terhadap faktur pajak yang tidak valid.

Atas dasar hasil temuan penelitian tersebut, dapat dikatakan bahwa penelitian ini telah sejalan dengan penelitian sebelumnya. Penelitian yang dilakukan oleh Mustari (2012) 
menghasilkan temuan pada PT. Kereta Api Pusat (Persero) yang sudah menjalankan PMK No.136/PMK.03/2012 dengan baik, namun dalam pelaksanaan pemungutan PPN ditemui permasalahan keterlambatan penyetoran PPN serta kesalahan pemindahbukuan yang dilakukan oleh staf keuangannya. Penelitian tersebut dilakukan pada tahun 2012 dimana PMK No.136/PMK.03/2012 baru ditetapkan sehingga perubahan mekanisme pemungutan PPN oleh pihak BUMN lain menyebabkan kesulitan baru yang harus dihadapi oleh staf keuangan. Permasalahan yang terjadi mengakibatkan penyerahan PPN terutang menjadi lebih bayar.

\subsection{Analisis Penyetoran Pajak Pertambahan Nilai}

Berdasarkan hasil observasi dan wawancara langsung terhadap beberapa karyawan bagian keuangan, dapat diketahui bahwa dalam melakukan penyetoran pajaknya, PT PGE Area Kamojang sudah sesuai dengan PMK No.136/PMK.03/2012 yaitu penyetoran PPN WAPU paling lambat pada tanggal 15 bulan berikutnya dengan melampirkan 5 rangkap SSP (Surat Setoran Pajak). Apabila tanggal jatuh tempo penyetoran pajak bertepatan dengan hari libur termasuk hari sabtu atau hari libur nasional maka penyetoran pajak dapat dilakukan pada hari berikutnya.

Dibalik kesesuaian akan peraturan yang berlaku tersebut, masih ditemui kendala pada tahun 2013 yakni terdapat salah satu vendor mengalami keterlambatan dalam melakukan penyetoran PPN. Penyetoran PPN dilakukan pada tanggal 25 untuk bulan yang bersangkutan. Apabila dalam melakukan penyetoran telah melewati dari bulan yang seharusnya maka vendornya sendiri dapat merubah faktur pajak tersebut untuk diperbaiki. Namun vendor tersebut tidak melakukan perubahan atas faktur pajaknya sehingga apabila PT. PGE tidak menginginkan keterlambatan, maka penyetoran PPN tetap harus dilakukan meskipun pelaporannya tidak dapat dilaksanakan.

Alasan vendor tidak memperbaiki faktur pajaknya adalah karena adanya closing keuangan pada PT. PGE Area Kamojang. Atas keterlambatan tersebut PT. PGE Area Kamojang dapat dikenakan sanksi administrasi. Namun, hingga saat ini belum terjadi adanya temuan dari pihak Kantor Pelayanan Pajak terkait dengan pelaporan tersebut.

Hasil penelitian ini sejalan dengan penelitian Kurnia (2017) yang dilakukan di Pusat Pengembangan Sumber Daya Minyak dan Gas Bumi (PPSDM Migas). Hasil penelitian tersebut menunjukan bahwa PPSDM Migas telah melakukan penyetoran pajaknya sesuai dengan mekanisme yang tercantum pada peraturan yang berlaku. Penyetoran pajak tersebut sesuai dengan waktu yang disyaratkan, namun masih ditemukan kesalahan dalam hal penyerahan faktur pajak dan SSP yang disebabkan oleh kelalaian pihak PPSDM Migas.

\subsection{Analisis Pelaporan Pajak Pertambahan Nilai}

Secara garis besar, pelaporan PPN pada PT PGE Area Kamojang sudah sesuai dengan PMK No.136/PMK.03/2012 dan Peraturan Direktur Jenderal Pajak Nomor PER-01/PJ/2017 Tentang Penyampaian Surat Pemberitahuan Elektronik. Surat Pemberitahuan Masa Pajak Pertambahan Nilai pada PT Pertamina Geothermal Energy Area Kamojang pun dibuat dalam tiga rangkap sesuai dengan aturan yang berlaku .Namun terjadi suatu peristiwa luar biasa, yaitu pelaporan PPN dengan cara disetahunkan pada tahun 2014. Hal ini mengakibatkan ketiadaan transaksi yang muncul mengenai PPN pada bulan yang bersangkutan namun transaksi-transaksi tersebut akan muncul sekaligus di akhit tahun. Dikarenakan hal tersebut, vendor akan meminta bukti potong kepada PT. PGE untuk periode satu tahun. Akibatnya, PT. PGE Area Kamojang khususnya bagian administrasi perpajakan akan overload pekerjaan. Hal ini akan terasa berat mengingat sumber daya manusia pada bagian administrasi perpajakan di PT. PGE Area Kamojang hanya berjumlah satu orang saja.

Penelitian ini sejalan dengan penelitian Eko Supriano (2015). Penelitian tersebut menyimpulkan bahwa PMK No.136/PMK.03/2012 dalam hal pelaporan PPN, telah dijalankan oleh PT Semen Indonesia (Persero) Tbk. Perbedaannya, dalam penelitian tersebut terdapat peristiwa luar biasa yakni kesalahan yang terjadi adalah kesalahan karyawan PT. Semen Indonesia dalam hal perhitungan Pajak Pertambahan Nilainya. 
4.6 Hasil Temuan Permasalahan pada PT Pertamina Geothermal Energy Area Kamojang Permasalahan yang ditemukan peneliti pada PT. PGE Area Kamojang sehubungan dengan penerapan PMK No.136/PMK.03/2012 adalah :

a) PT. PGE Area Kamojang beresiko untuk dikenai denda administrasi perpajakan karena keterlambatan pelaporan PPN. Hal ini disebabkan karena vendor yang terkadang tidak menerbitkan faktur pajak di masa yang sama sesuai dengan masa penyerahan barang dan jasa kena pajak. Dapat ditarik asumsi bahwa permasalahannya (dari tahun 2015 hingga 2018) terletak pada Standard Operation Procedure (SOP) vendor terkait mengenai penerbitan faktur pajak.

b) Kesalahan input data faktur pajak seperti alamat kantor,tanggal, nomor seri faktur pajak dan kecacatan faktur pajak ditemui di tahun 2018.

c) Pada tahun 2013 ditemukan kesenjangan praktik dengan peraturan yang berlaku, yaitu penyetoran pajak yang seharusnya dilakukan pada tanggal 25, tidak dilakukan oleh vendor. Faktur pajak pun tidak diperbaiki dengan alasan adanya closing keuangan PT. PGE Area Kamojang.

d) Vendor menyerahkan faktur PPN dengan cara disetahunkan. Hal ini menyebabkan transaksi yang muncul sekaligus pada akhir tahun sehingga vendor pun meminta bukti potong kepada PT. PGE Area Kamojang untuk periode 1 tahun secara sekaligus. Akibatnya terjadi overload pekerjaan administrasi perpajakan. Peristiwa ini terjadi pada tahun 2014

e) Ketidakvalidan faktur pajak yang diserahkan oleh vendor ditemukan pada tahun 2016. Selain itu pada tahun 2017 ditemukan kesalahan yang diakibatkan oleh ketidaktelitian vendor dalam pencantuman alamat PT. PGE Area Kamojang pada faktur pajaknya.

\subsection{Rekomendasi Solusi atas Permasalahan pada PT Pertamina Geothermal Energy Area Kamojang}

a) Menyikapi permasalahan penerbitan faktur pajak yang terkadang tidak selaras dengan masa penyerahan barang dan jasa kena pajak, hendaknya mekanisme pembuatan faktur pajak dikomunikasikan secara terperinci dengan perusahaan rekanan. Perlu ditegaskan pula konsekuensi yang dapat timbul apabila sebelumnya terdapat ketidakselarasan antara masa penerbitan faktur pajak dengan masa penyerahan barang dan jasa kena pajak kemudian vendor tidak melakukan pembetulan atas faktur pajak tersebut.

b) Apabila terdapat kekeliruan dalam pencantuman alamat kantor, tanggal maupun terdapat kecacatan faktur pajak, maka dapat diatasi dengan mencantumkan kode 031 pada faktur pajak.

c) Bagi vendor yang mengalami kesalahan dalam pembuatan faktur pajaknya, atau melakukan penyetoran melebihi waktu yang seharusnya, PT. PGE Area Kamojang dapat meminta vendor tersebut untuk merubah faktur pajak dan mencantumkan kode 031. Khusus untuk vendor yang mengalami keterlambatan penyetoran pajak, tetap harus menyetorkan pajak walaupun tidak dapat melaksanakan pelaporan PPN.

d) Dalam rangka efisiensi dan efektivitas pekerjaan bagian administrasi perpajakan, penambahan sumber daya manusia di bagian tersebut dapat menjadi solusi. Tentunya dengan mempertimbangkan cost dan benefitnya.

\section{KESIMPULAN}

Mengacu pada pemaparan sebelumnya, maka kesimpulan yang dapat diambil adalah sebagai berikut:

1. Proses Pemungutan PPN yang dilakukan oleh PT PGE Area Kamojang adalah mengajukan dokumen verifikator maksimal 2 (dua) hari kerja sejak memo/nota pengantar di terima oleh user. Setelah itu diperiksa dan disetujui oleh Manager Keuangan sehingga dapat dilakukan proses penagihan. Jika pembelian jasa selesai maka bisa memasuki termin pembayaran, setelah itu perusahaan dapat menggunakan dokumen berupa kwitansi. Selanjutnya, bagian 
kontroler memeriksa kebenaran dari kwitansi dan faktur pajak yang terkait. Sistem yang digunakan dalam pemungutan Pajak Pertambahan Nilai ini menggunakan aplikasi SAP (System Application and Product in data Processing).

2. Realisasi pelaksanaan pembayaran PPN pada PT PGE Area Kamojang sebagai wajib pungut (mencakup perhitungan, pemungutan, penyetoran dan Pelaporan PPN) sudah sesuai dengan Peraturan kebijakan pemerintah No.136/PMK.03/2012 dan Undang-Undang No. 42 Tahun 2009.

3. Pelaksanaan pembayaran PPN yang dilakukan PT. PGE mengalami beberapa kendala seperti adanya ketidaksesuaian faktur pajak yang diterbitkan dengan periode penyerahan barang dan jasa kena pajak, keterlambatan penyetoran PPN yang diakibatkan vendor tidak melakukan perbaikan faktur pajak, penyerahan faktur pajak dari vendor dengan cara disetahunkan dan vendor menyerahkan faktur pajak yang tidak valid atau cacat.

4. Solusi yang ditawarkan untuk permasalahan di atas adalah adanya komunikasi yang efektif antara PT. PGE dan pihak rekanan terkait mekanisme pemungutan PPN dan pembetulan faktur pajak. Selain itu, penambahan sumber daya manusia bagian administrasi perpajakan juga dapat menjadi masukan, dengan mempertimbangkan cost dan benefitnya.

\section{DAFTAR PUSTAKA}

Aditya, Kurnia (2017). Analisis Penerapan KMK No.563/KMK.03/2003 Tentang Penunjukkan Bendaharawan Pemerintah Sebagai Wajib Pungut Pajak Pertambahan Nilai Pada Pusat Pengembangan Sumber Daya Minyak dan Gas Bumi (PPSDM) Migas. Thesis. 2017

Eko, Supriano (2015). Analisis Penerapan Pajak Pertambahan Nilai (PPN) Studi Atas Pencatatan dan Perhitungan PPN Pada PT Semen Indonesia (Persero) Tbk.Thesis. 2015

Hafidhotul, ilmi (2016). Analisis Penerapan Pajak Pertambahan Nilai pada PT. Jen Tsong Indonesia. Thesis. 2016

KementerianKeuangan.Apbn-Kita-Edisi-September-2018.pdf. https://www.kemenkeu.go.id/media/10576/apbn-kita-edisi-september-2018.pdf. September 2018]

KementerianKeuangan.Apbn-Kita-Edisi-November-2018.pdf. https://www.kemenkeu.go.id/media/10576/apbn-kita-edisi-november-2018.pdf. [31 Maret 2020]

Kementerian Keuangan. Penerimaan Pajak Utama Terbesar Berasal dari PPN. https://databoks.katadata.co.id/datapublish/2018/12/13/penerimaan-pajak-utama. Desember 2018]

Mardiasmo. (2011). Perpajakan Edisi Revisi 2011. Yogyakarta : Penerbit Andi.

Mustari (2012). Tinjauan Atas Kewajiban Pemungutan Pajak Pertambahan Nilai Pada pt Kereta Api Indonesia (Persero) Bandung.Jurnal Pajak Pertambahan Nilai Vol.1,Juli 2012, hlm1-8.

Pemerintah Republik Indonesia, Undang-undang nomor 16 Tahun 2009, Tentang Ketentuan Umum dan Tata Cara Perpajakkan.

Pemerintah Republik Indonesia, Undang-undang 42 Tahun 2009, Tentang Pajak Pertambahan Nilai Barang dan Jasa dan Pajak Penjualan Atas Barang Mewah.

Suandy.(2011). Perencanaan Pajak. Edisi 6.Jakarta : Salemba Empat.

Waluyo. (2009). Akuntansi Pajak . Jakarta : Salemba Empat. 


\section{Biodata Penulis}

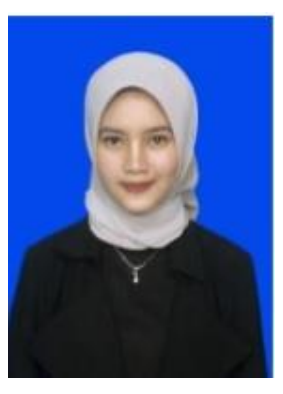

Norma Etika Wati lahir di Sukabumi pada tanggal 28 September 1997. Norma menempuh pendidikan Diploma IV di Jurusan Akuntansi Politeknik Negeri Bandung dan lulus pada tahun 2019. Saat ini Norma tengah bekerja di MCI Grup.

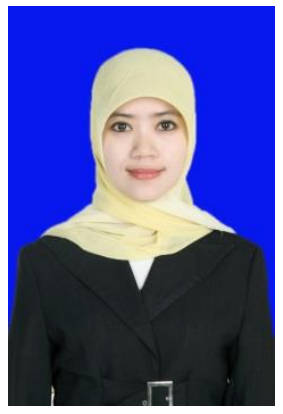

Kamalah Saadah lahir di Bandung pada tanggal 15 Januari 1989. Kamalah menempuh pendidikan S1 di Universitas Pendidikan Indonesia Jurusan Pendidikan Akuntansi dan lulus pada tahun 2010, kemudian melanjutkan S2 di Universitas Padjadjaran dan lulus pada tahun 2013. Pada tahun 2013 sampai dengan tahun 2019 Kamalah berprofesi sebagai Dosen di Politeknik Negeri Bandung dan saat ini Kamalah tengah bekerja sebagai Dosen di Universitas Swadaya Gunung Jati Cirebon. 